\author{
Marek KIEROŃCZYK ${ }^{1}$ \\ Tadeusz MARCINKOWSKI ${ }^{2}$
}

\title{
GOSPODARSTWO ROLNE JAKO ŹRÓDLO EMISJI AMONIAKU
}

\begin{abstract}
Celem pracy było określenie wpływu emisji amoniaku z gospodarskich składowisk obornika na jakość powietrza na terenach wiejskich oraz ocena czynników wpływających na wielkość tej emisji. W latach 2003-2007 wykonano ponad 100 dobowych pomiarów emisji amoniaku ze składowisk obornika w wybranych gospodarstwach o mlecznym profilu produkcji stosując mikrometeorologiczną metodę dozymetrii pasywnej. Badania przeprowadzono w typowych warunkach eksploatacyjnych. Wykazały one, że roczna emisja amoniaku kształtowała się od 318 do $698 \mathrm{kgN}-\mathrm{NH}_{3}$ co stanowiło, że roczne straty azotu wynosiły od 35,2 do 44,0\% w stosunku do ilości azotu pierwotnie zdeponowanej na składowisku. Do oceny emisji amoniaku zaproponowano model matematyczny, który zawiera najważniejsze czynniki techniczno-technologiczne i meteorologiczne wpływające na ulatnianie się amoniaku z gnojowni w warunkach ciągłej jej eksploatacji.
\end{abstract}

Słowa kluczowe: gospodarstwo, obornik, przechowywanie, emisja amoniaku

\section{Wstęp}

Uwalnianie się gazów cieplarnianych i amoniaku, do atmosfery ze źródeł rolniczych stanowi istotny problem środowiskowy i ekonomiczny. Szczególnie duże ilości amoniaku uwalniają się w wyniku prowadzenia intensywnej produkcji rolnej. W krajach Unii Europejskiej problemy zanieczyszczenia powietrza są niezwykle ważnym elementem polityki ochrony środowiska oraz ochrony zdrowia i życia ludzi. Rolnictwo stanowi główne źródło zanieczyszczenia środowiska nieorganicznym azotem $\mathrm{w}$ formie zredukowanej $[10,13]$. W latach 80. $\mathrm{XX}$ w. w obliczu relatywnie niskiego poziomu cen nawozów mineralnych nastąpiło stopniowe zwiększanie dawek tych nawozów, w tym nawozów azotowych, stosowanych na gruntach rolnych. Zjawisko to stało się przyczyną zaburzenie równowagi występowania składników nawozowych w środowisku [15].

\footnotetext{
${ }^{1}$ Autor do korespondencji/corresponding author: Marek Kierończyk, Instytut TechnologicznoPrzyrodniczy w Falentach Żuławski Ośrodek Badawczy w Elblągu, 82-300 Elbląg ul. Giermków 5, +55 2324788, m.kieronczyk@itp.edu.pl

${ }^{2}$ Tadeusz Marcinkowski, Państwowa Wyższa Szkoła Zawodowa w Elblągu, 82-300 Elbląg, ul. Grunwaldzka 137, +55 6290610, t.marcinkowski@ pwsz.elblag.pl
} 
Od lat 50. XX w. systematycznie wzrastał również udział azotu, pochodzącego z rolnictwa, w zanieczyszczeniu środowiska naturalnego. Wielu autorów $[1,2,3,5,7]$ we wzroście intensywności produkcji zwierzęcej upatruje główne przyczyny tych zmian. Chów zwierząt inwentarskich, w tym bydła mlecznego, charakteryzuje się znacznymi stratami azotu pochodzącego z odchodów zwierzęcych. Azot ten rozpraszany jest do gleby, wody i powietrza $[15,17]$.

Emisja azotu w formie amoniaku podczas zagospodarowywania nawozów naturalnych w gospodarstwie rolnym szacowana jest na około $80 \%$ całkowitej emisji ze źródeł rolniczych $[1,14]$. Pozostałe $20 \%$ pochodzi przede wszystkim $\mathrm{z}$ rozpraszania azotu zawartego w syntetycznych nawozach azotowych, w tym z saletry amonowej i mocznika, dość powszechnie stosowanych w nawożeniu roślin $[14,15]$.

W gospodarstwie rolnym, na etapie wytwarzania nawozów naturalnych (obornik, gnojówka, gnojowica) w budynkach inwentarskich straty azotu w formie amoniaku wynoszą około 10\% [9], na etapie ich przechowywania kształtują się na poziomie od 20 do 50\% [4, 11], na etapie aplikacji na gruntach rolnych stanowią 25-95\% [15], a na pastwiskach mogą wynosić około $15 \%$ [15, 14]. Wyzwaniem dla nauki jest poszukiwanie skutecznych sposobów ograniczania strat azotu, w tym gazowego amoniaku $\mathrm{z}$ rolnictwa, między innymi poprzez wdrażanie niskoemisyjnych technologii przechowywania nawozów naturalnych.

Celem niniejszej pracy było określenie wpływu emisji amoniaku z gospodarskich składowisk obornika na jakość powietrza na terenach wiejskich oraz określenie czynników, które istotnie wpływają na wielkość tej emisji. Badania uwzględniały rzeczywiste warunki przechowywania nawozów naturalnych w typowych gospodarstwach rolnych.

\section{Metodyka badań}

Badania emisji amoniaku z gospodarskich składowisk nawozów naturalnych prowadzono w latach 2003-2007 w wybranych, towarowych gospodarstwach rolnych położonych na Żuławach Elbląskich, które umownie oznaczono symbolami: G1, G2 i G3 (tab. 1). Dobowy strumień amoniaku uwalnianego do atmosfery oznaczano techniką mikrometeorologicznej dozymetrii pasywnej z wykorzystaniem próbników (dozymetrów) strumieniowych $[6,8,16]$.

Istotę pomiaru stanowi chemiczna sorpcja amoniaku przepływającego nad powierzchnią sorbentu - kwas szczawiowy, którym uprzednio powleczono wewnętrzne ścianki próbników. Czas ekspozycji próbników wynosił 24 godziny. Otrzymany w wyniku sorpcji amoniaku szczawian amonowy ekstrahowano z próbników wodą demineralizowaną, a stężenie kationu amonowego oznaczano spektrofotometrycznie. Szczegółowy opis stosowanej metody został przedstawiony we wcześniejszym opracowaniu [8]. 
Jednocześnie prowadzono stały monitoring wybranych parametrów meteorologicznych, takich jak temperatura powietrza $T_{\text {pow }}$, prędkość wiatru $v$, wilgotność względną powietrza $\mathrm{Wg}$. Ponadto wykonywano pomiary temperatury stosu obornika $T_{\text {pr }}$ (na głębokości $20 \mathrm{~cm}$ ), a dla potrzeb analiz chemicznych (zawartość azotu w nawozie) pobierano próbki nawozu deponowanego na składowisku. Badania prowadzono w warunkach ciągłej eksploatacji gnojowni, tj. codziennego dostarczania na składowisko kolejnych porcji świeżego nawozu. Ogólna charakterystyka badanych obiektów przedstawia się w sposób następujący (tab. 1).

Gospodarstwo G1. Obiektem badawczym była płyta gnojowa o powierzchni $176 \mathrm{~m}^{2}$, otoczona $\mathrm{z}$ trzech stron murem oporowym o wysokości $0,2 \mathrm{~m}$. Wykorzystanie powierzchni płyty gnojowej wynosiło od 68 do $94 \%$, a średnia wysokość pryzmy 2,0-2,5 m. Obornik z budynku inwentarskiego usuwano ręcznie. Dziennie dostarczano na pryzmę od 0,75 do 2,50 Mg świeżego obornika zależnie od pory roku.

Gospodarstwo G2. Obiektem badawczym była płyta gnojowa o powierzchni $144 \mathrm{~m}^{2}$ (bez muru oporowego) z centralnie usytuowaną kratką na odcieki kierowane do podziemnego zbiornika na gnojówkę. Wykorzystanie powierzchni przeznaczonej do składowania wynosiło od 52 do $96 \%$, a średnia wysokość pryzmy $3,0 \mathrm{~m}$. W tym gospodarstwie, z powodu ograniczonej powierzchni składowania stosowano minimalne ilości ściółki dla zwierząt. Na składowisko obornika dostarczano od 0,5 do $1,7 \mathrm{Mg}$ świeżego obornika w ciągu doby.

Gospodarstwo G3. Obiekt badawczy stanowiła płyta gnojowa o powierzchni $135 \mathrm{~m}^{2} \mathrm{z}$ murem oporowym o wysokości $1,5 \mathrm{~m}$ (z dwóch stron). W centralnym miejscu płyty znajdowała się kratka na odcieki, które odprowadzano do podziemnego zbiornika na gnojówkę. W tym gospodarstwie wykorzystanie powierzchni płyty gnojowej kształtowało się od 45 do $88 \%$, przy średniej wysokości pryzmy około $2,0 \mathrm{~m}$. Ilość dostarczanego na płytę świeżego obornika wynosiła od ok. 0,5 do 1,5 Mg w ciągu doby.

Tabela 1. Charakterystyka płyt gnojowych w gospodarstwach

Table 1. Characteristic of farm yard manure pits at farms

\begin{tabular}{|c|c|c|c|}
\hline Gospodarstwo & $\begin{array}{c}\text { Powierzchnia } \\
\text { płyty } \\
\text { gnojowej } \\
{\left[\mathbf{m}^{2}\right]}\end{array}$ & $\begin{array}{c}\text { Średnia ilośćc } \\
\text { dostarczanego } \\
\text { obornika } \\
{[\mathbf{M g} / \mathbf{d z i e n}]}\end{array}$ & $\begin{array}{c}\text { Wykorzystanie } \\
\text { powierzchni płyty } \\
\text { gnojowej } \\
{[\%]}\end{array}$ \\
\hline G1 & 176 & $0,7-2,5$ & $68-94$ \\
\hline G2 & 144 & $0,5-1,7$ & $52-96$ \\
\hline G3 & 135 & $0,5-1,5$ & $40-94$ \\
\hline
\end{tabular}


Do oceny statystycznej uzyskanych wyników badań i opracowania modelu matematycznego, opisującego emisję amoniaku z gnojowni wykorzystano program statystyczny Statistica stosując metodę regresji krokowej wstecz.

\section{Wyniki badań}

Średnia masa amoniaku uwalnianego do atmosfery $\mathrm{z}$ gnojowni $\mathrm{w}$ gospodarstwie G1 w ciągu doby kształtowała się w przedziale od 0,9 do $3,0 \mathrm{~kg}$ $\mathrm{N}^{-\mathrm{NH}_{3}}$ (tab. 2), a szacowana roczna wielkość emisji wynosiła $698 \mathrm{~kg} \mathrm{~N}$. Warunki meteorologiczne panujące $\mathrm{w}$ otoczeniu pryzmy w gospodarstwie G1 przedstawiały się następująco: średnia dobowa prędkość wiatru $v$ wynosiła od 0,8 do 4,1 (m/s), a średnia dobowa wilgotność względna powietrza $W g$ kształtowała się w przedziale od 67 do $93 \%$. Z kolei parametry technologiczne związane z przechowywaniem obornika na pryzmach tj. zawartość suchej masy w nawozie $S M$ oraz całkowita ilość azotu zdeponowanego na pryzmie $N_{\text {tot }}$, kształtowały się odpowiednio: 18,0-24\% i 1226-2204 kg N. Zdecydowanie największą emisję amoniaku $\mathrm{z}$ gnojowni stwierdzono $\mathrm{w}$ okresie jesiennozimowym, tj. w czasie, gdy masa codziennie dostarczanego nawozu na składowisko była największa. W gospodarstwie tym stosowano również stosunkowo dużą ilość ściółki (> $5 \mathrm{~kg}$ na zwierzę inwentarskie), co mogło dodatkowo wpływać na zwiększenie emisji amoniaku.

Masa ulatniającego się $\mathrm{w}$ ciągu doby amoniaku $\mathrm{z}$ gnojowni $\mathrm{w}$ gospodarstwie G2 (tab. 2) wynosiła od 0,7 do $2,1 \mathrm{~kg} \mathrm{~N}-\mathrm{NH}_{3}$ a szacowana roczna wielkość emisji wynosiła $408 \mathrm{~kg}$ N. Podobnie jak w gospodarstwie G1 występowała sezonowa zmienność masy ulatniającego się amoniaku z gnojowni. Jednak bezwzględna masa emitowanego gazu była wyraźnie mniejsza niż w gospodarstwie G1. W znacznym stopniu należy to tłumaczyć stosowanymi w tym gospodarstwie sposobami zagospodarowania nawozu podczas jego przechowywania, w tym ograniczaniem powierzchni pryzmy przez podwyższanie stosu z obornikiem oraz zdecydowanie mniejszą ilością stosowanej ściółki $(<4 \mathrm{~kg}$ na zwierze inwentarskie). W gospodarstwie G2 warunki meteorologiczne panujące wokół pryzmy kształtowały się następująco: średnia dobowa prędkość wiatru kształtowała się w przedziale 0,6-4,5 $(\mathrm{m} / \mathrm{s})$, średnia dobowa wilgotność względna powietrza $W g$ wynosiła 70-97\%. Parametry technologiczne tj. zawartość suchej masy $S M$ w nawozie oraz ilość azotu zdeponowanego na pryzmie $N_{\text {tot }}$ wynosiły odpowiednio: $16,5-25,3 \%$ i $320-1140 \mathrm{~kg} \mathrm{~N}$.

Dobowa emisja amoniaku z płyty gnojowej w gospodarstwie G3 (tab. 2) zawierała się w przedziale od 0,5 do $1,6 \mathrm{~kg} \mathrm{~N}-\mathrm{NH}_{3}$ a szacowana roczna wielkość emisji wynosiła $318 \mathrm{~kg}$ N.. Sezonowość w ocenie dobowej emisji amoniaku z gnojowni w gospodarstwie G3 kształtowała się podobnie, jak w gospodarstwach G2 i G3. Warunki meteorologiczne kształtowały się podobnie jak wokół obiektów G1 i G2 i wynosiły: średnia dobowa prędkość wiatru od 0,5 do 4,4 $(\mathrm{m} / \mathrm{s})$, średnia dobowa wilgotność względna powietrza 68-98\%. Wielkości 
związane z parametrami technologicznymi tj. zawartość suchej masy $S M$ w nawozie oraz ilość azotu zdeponowanego na pryzmie $N_{\text {tot }}$ wynosiły odpowiednio: $19,4-21,0 \%$ i $107-1484 \mathrm{~kg} \mathrm{~N}$.

Tabela 2. Średnia dobowa oraz szacowana roczna emisja amoniaku z gnojowni w wybranych gospodarstwach

Table 2. Average daily and estimated annual ammonia emission from farm yard manure pits in selected farms

\begin{tabular}{|c|c|c|c|c|c|c|}
\hline \multirow{4}{*}{ Miesiąc } & \multicolumn{6}{|c|}{ Gospodarstwo } \\
\hline & \multicolumn{2}{|c|}{$\begin{array}{c}\text { G1 } \\
n=54\end{array}$} & \multicolumn{2}{|c|}{$\begin{array}{c}\mathbf{G 2} \\
n=37\end{array}$} & \multicolumn{2}{|c|}{$\begin{array}{c}\text { G3 } \\
n=39\end{array}$} \\
\hline & $\begin{array}{l}\text { średnia } \\
\text { dobowa } \\
\text { emisja }\end{array}$ & $\begin{array}{c}\text { średnia } \\
\text { powierzchnia } \\
\text { płyty } \\
\text { zajmowana } \\
\text { przez } \\
\text { obornik }\end{array}$ & $\begin{array}{l}\text { średnia } \\
\text { dobowa } \\
\text { emisja }\end{array}$ & $\begin{array}{c}\text { średnia } \\
\text { powierzchnia } \\
\text { płyty } \\
\text { zajmowana } \\
\text { przez } \\
\text { obornik }\end{array}$ & $\begin{array}{c}\text { średnia } \\
\text { dobowa } \\
\text { emisja }\end{array}$ & $\begin{array}{c}\text { średnia } \\
\text { powierzchnia } \\
\text { płyty } \\
\text { zajmowana } \\
\text { przez } \\
\text { obornik }\end{array}$ \\
\hline & $\begin{array}{c}{[\mathrm{kg} \mathrm{N}-} \\
\left.\mathrm{NH}_{3}\right] \\
\end{array}$ & {$\left[\mathrm{m}^{2}\right]$} & $\begin{array}{c}{[\mathrm{kg} \mathrm{N}-} \\
\left.\mathrm{NH}_{3}\right] \\
\end{array}$ & {$\left[\mathrm{m}^{2}\right]$} & $\begin{array}{c}\mathrm{kg} \mathrm{N}- \\
\left.\mathrm{NH}_{3}\right] \\
\end{array}$ & {$\left[\mathrm{m}^{2}\right]$} \\
\hline $\mathrm{I}$ & 3,0 & 142 & 1,4 & 139 & 1,4 & 126 \\
\hline II & 2,1 & 150 & 1,2 & 138 & 1,1 & 118 \\
\hline III & 1,6 & 157 & 0,9 & 138 & 0,9 & 104 \\
\hline IV & 2,3 & 165 & 1,0 & 134 & 0,6 & 85 \\
\hline $\mathrm{V}$ & 1,1 & 153 & 0,9 & 121 & 0,7 & 117 \\
\hline VI & 0,9 & 151 & 0,8 & 107 & 0,5 & 122 \\
\hline VII & 1,5 & 152 & 0,7 & 75 & 0,6 & 127 \\
\hline VIII & 1,6 & 136 & 1,3 & 90 & - & - \\
\hline IX & 1,2 & 124 & - & - & 0,9 & 54 \\
\hline$X$ & 2,3 & 120 & 1,2 & 80 & 1,2 & 55 \\
\hline $\mathrm{XI}$ & 2,6 & 141 & 2,1 & 126 & 1,2 & 88 \\
\hline XII & 2,8 & 151 & 2,1 & 138 & 1,6 & 123 \\
\hline 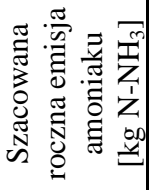 & & 698 & & 08 & & 318 \\
\hline
\end{tabular}

Największe straty amoniaku na składowiskach obornika notowano w miesiącach zimowych, kiedy zwierzęta przebywały w budynkach inwentarskich całą dobę. We wszystkich gospodarstwach warunki meteorologiczne na badanych obiektach były zbliżone zaś duża ilość odchodów zwierzęcych deponowanych na gnojowni w okresie jesienno-zimowym powodowała wzrost emisji amoniaku. W przypadku okresu letniego ilość traconego amoniaku na gnojowniach była relatywnie niższa, pomimo wyższych średnich dobowych temperatur 
powietrza. Jednak ilości dostarczanego na pryzmę nawozu w tym okresie były znacznie mniejsze (zwierzęta przebywały na pastwisku).

Roczne straty azotu w gospodarstwach kształtowały się w przedziale od 35,2 do 44,0\% (tab. 3) w stosunku do ilości azotu pierwotnie zdeponowanego na składowisku. Średnie roczne wielkości emisji amoniaku odniesione do powierzchni zajmowanej przez obornik kształtowały się w szerokim zakresie od 3,1 do $4,8 \mathrm{kgN} / \mathrm{m}^{2}$ i odzwierciedlały różnice $\mathrm{w}$ sposobie przechowywania obornika pomiędzy badanymi obiektami (tab. 3 ).

Dotychczas wykonano wiele badań dotyczących szacowania emisji $\mathrm{NH}_{3} \mathrm{ze}$ statycznych składowisk obornika $[9,14,15,16]$. Nie przeprowadzano jednak badań podczas ciągłego użytkowania gnojowni, co ma miejsce w typowym gospodarstwie rolnym. Wyjątek stanowią pilotażowe prace wykonane w IMUZ w latach 1996-2002 przez Marcinkowskiego [12]. Szacowanie metodami ilościowymi emisji amoniaku z opisanych w pracy składowisk nawozów naturalnych z uwzględnieniem techniczno-technologicznych warunków ich składowania oraz czynników meteorologicznych można uznać za ważny element poznawczy.

Tabela 3. Ocena rocznych strat azotu na gnojowniach w badanych gospodarstwach

Table 3. Assessment of annual losses of nitrogen at farm yard manure in selected farms

\begin{tabular}{|c|c|c|c|}
\hline \multirow{2}{*}{$\begin{array}{c}\text { Straty } \\
\text { azotu }\end{array}$} & \multicolumn{3}{|c|}{ Gospodarstwo } \\
\cline { 2 - 4 } & $\mathrm{G} 1$ & $\mathrm{G} 2$ & $\mathrm{G} 3$ \\
\hline$\% \mathrm{~N}^{1)}$ & 42,8 & 44,0 & 35,2 \\
\hline $\mathrm{kg} \mathrm{N} / \mathrm{m}^{22}$ & 4,8 & 3,5 & 3,1 \\
\hline
\end{tabular}

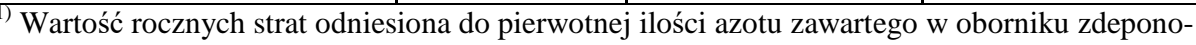
wanym na gnojowni

${ }^{2)}$ Wartość rocznych strat odniesiona do średniej powierzchni płyty zajmowanej przez obornik $S$

Korzystając z metod analizy statystycznej podjęto również próbę opracowania modelu opisującego emisję amoniaku na gnojowni w gospodarstwie rolnym. Doboru zmiennych dokonano w oparciu o metodę regresji krokowej wstecz. Ostateczny kształt równania modelu osiągnięto po wykonaniu siedmiu kroków. Końcowym etapem było wyznaczenie równania regresji linowej $\left(\mathrm{R}^{2}=0,80\right)$.

$$
E_{g N H_{3}}=61,3 S M+0,37 N_{t o t}+18,4 \Delta T+97,3 v+10,4 W g-123,1 P_{j}-1654
$$

gdzie: SM - zawartość suchej masy w nawozie

$N_{\text {tot }}$ - całkowita ilość azotu w nawozie na składowisku

$\Delta T$ - gradient temperatury

$\mathrm{v}$ - prędkość wiatru

$P_{\mathrm{j}} \quad$ - parametr jakościowy 
W równaniu modelowym zawarto czynniki (zmienne niezależne) techniczno-technologiczne i meteorologiczne, które wpływają na emisję amoniaku w sposób statystycznie istotny. W przyjętym modelu czynnikami technicznotechnologicznymi były: zawartość suchej masy $S M$ w nawozie, ilość azotu zdeponowanego na pryzmie nawozu $N_{\text {tot }}$, gradient temperatury $\Delta T$ (różnica temperatury pomiędzy temperaturą pryzmy $T_{\mathrm{pr}}$, a temperaturą powietrza otaczającego pryzmę nawozu $T_{\text {pow }}$ ) parametr jakościowy $P_{j}$ opisujący sposób składowania nawozu, czynnikami meteorologicznymi zaś prędkość wiatru $v$ oraz wilgotność względna powietrza $W g$.

Zróżnicowana w szerokim zakresie (od 16,5 do 25,3\%) zawartość suchej masy $S M$ w oborniku jest ściśle powiązana z ilością ściółki (najczęściej słomy) stosowanej w poszczególnych gospodarstwach.

Całkowita zawartość azotu zdeponowanego na gnojowni $N_{\text {tot }}$ jest związana ze sposobem żywienia zwierząt, który znacznie różni się w poszczególnych gospodarstwach. Wielkość tego parametru kształtowała się w szerokim zakresie $107-2204 \mathrm{~kg} \mathrm{~N}$.

Gradient temperatury $(\Delta T)$ to parametr ściśle związany ze sposobem przechowywania obornika na pryzmie. Ugniatanie i zmniejszanie powierzchni zajmowanej na gnojowni przez obornik wpływa na zmniejszenie parametru $\Delta T$ i ograniczenie emisji amoniaku. Wartość $\Delta T$ zawierała się w zakresie od 2 do $29^{\circ} \mathrm{C}$.

Prawidłowość formowania pryzmy obornikowej została opisana parametrem jakościowym $P_{\mathrm{j}}$. Przyjęto założenie występowania trzech sposobów przechowywania nawozu: 1 - nieprawidłowy sposób formowania pryzmy (luźno bez ugniatania); 2 - zadowalający (częściowe ugniatanie i zmniejszanie powierzchni obornika); 3 -prawidłowy zgodny z zaleceniami „Kodeksu dobrej praktyki rolniczej".

Wśród czynników meteorologicznych w równaniu modelowym uwzględniono prędkość wiatru $v$ oraz wilgotność względna powietrza $W g$, których wartości mierzono podczas wykonywania pomiarów emisji amoniaku na gnojowniach w każdym z gospodarstw.

\section{Wnioski}

Gospodarstwa rolne zajmujące się produkcją zwierzęcą są odpowiedzialne za rozpraszanie znacznych ilości gazowych związków azotu, w tym amoniaku, do środowiska przyrodniczego. Dotychczas podejmowane działania, mające na celu ograniczenie tego rodzaju strat azotu, powinny zostać zintensyfikowane i uzyskać status działań o wysokim priorytecie.

Ponieważ czynniki techniczno-technologiczne i meteorologiczne determinują ulatnianie się amoniaku z pryzm obornika działania ograniczające emisję amoniaku powinny być skoncentrowane na ograniczaniu powierzchni składowania obornika i na jego mechanicznym ugniataniu. 
Powyższe wyniki badań upoważniają do przedstawienia następujących wniosków:

- W badanych gospodarstwach rolnych roczne straty azotu w formie amoniaku na etapie składowania obornika wynosiły od 35,2 do 44,0 \% w stosunku do pierwotnej jego zawartości w nawozie.

- Na emisję amoniaku z pryzm istotny wpływ mają również czynniki meteorologiczne, w tym głownie prędkość wiatru $v$ oraz wilgotność względna powietrza $W g$.

- Opracowany model matematyczny służący do oceny wielkości emisji amoniaku z płyty gnojowej jest zgodny z danymi doświadczalnymi $\left(R^{2}=0,80\right)$.

\section{Literatura}

[1] Amon B., Amon T., Boxberger, Alt Ch., 2001. Emissions of $\mathrm{NH}_{3}, \mathrm{~N}_{2} \mathrm{O}$ and $\mathrm{CH}_{4}$ from dairy cows housed in farmyard manure tying stall (housing, manure storage, manure spreading). Nutrient Cycling in Agroecosystems. 60 (1-3) s. 103-113.

[2] Assman W.H., Sutton M., Schjorring J.K. 1998. Ammonia: emission, atmospheric transport and deposition. New Phytologist. Vol. 1. (139) s. 27-48.

[3] Balsari P., Airoldi G., Dinuccio E., Gioelli F., 2007. Ammonia emissions from farmyard manure heaps and slurry stores - Effect of environmental conditions and measuring methods. Biosystems Engineering. 97 (4) s. 456-463.

[4] Chadwick D.R. 2005. Emissions of ammonia, nitrous oxide and methane form cattle manure heaps effect of compaction and covering. Atmospheric Environment. Vol. 4 s. 787-799.

[5] Dach J. Zbytek Z., 2006. Biologiczne aspekty różnych metod zagospodarowania obornika. Nawozy i Nawożenie. 4 (29) s. 46-60.

[6] Ferm M., Marcinkowski T., Kierończyk M., Pietrzak S. 2005. Measurements of ammonia emissions from manure storing and spreading stages in Polish commercial farms. Atmospheric Environment. Vol. 39 s. 7106-7113.

[7] Jarvis S.C. 1994. The pollution potential and flows of nitrogen to waters and atmosphere from grassland under grazing. W: Pollution in livestock production systems. Pr. zbior. Red. I. Ap Dewi, R.F.E. Axford, M. Fayez, M. Marai, H.M. Omed. Wallingford. CAB International s. 227-239.

[8] Kierończyk M., Marcinkowski T. 2004. Pomiar emisji amoniaku ze źródeł rolniczych metodą mikrometeorologicznej dozymetrii pasywnej. Woda-Środowisko-Obszary Wiejskie. T. 4. Z. 2a (11) s. 537-546.

[9] Kuczyński T., Daemmgen U., Klimont Z., Kres-Tomczak K., Myczko A., SłobodzianKsenicz O., 2005. Ammonia emissions in Poland: inventory projections, uncertainties. w: Emissions from European agriculture. Wageningen. Wageningen Academic Publishers s. 217-230.

[10] Koerevaar H., 1992. The nitrogen balance on intensive Dutch dairy farm: a review. Livestock Production Science. Vol. 1-2 s. 17-27.

[11] Marcinkowski T. 2000. Emisja amoniaku z gospodarskich składowisk obornika w świetle pomiarów ilościowych. Zeszyty Naukowe AR Szczecin. Z. 84 s. 269-274. 
[12] Marcinkowski T., 2002. Identyfikacja strat azotu w towarowych gospodarstwach rolnych Żuław Wiślanych. Woda-Środowisko-Obszary Wiejskie. Rozprawy naukowe i monografie. 1 ss. 79.

[13] Peel S., Chambers B.J., Harisson R., Jarvis S.C. 1997. Reducing nitrogen emissions from complete dairy farm systems. W: Gaseous nitrogen emissions from grassland. Pr. zbior. Red. S.C. Jarvis, B.F. Pain. Wallingford. CAB International s. 383-390.

[14] Pietrzak S. 2006. Straty amoniaku z nawozów naturalnych i ich konsekwencje środowiskowe. Nawozy i Nawożenie. Nr 4 s. 186-203.

[15] Sapek A. 1995. Emisja amoniaku z produkcji rolnej. Postępy Nauk Rolniczych. Nr 2 s. 3-23.

[16] Schjoering J., Sommer S.G. Ferm M. 1992. A simple passive sampler for measuring ammonia emission in the field. Water, Air and Soil Pollution. Vol. 62 s. 13-24. 102

[17] Tamminga S. 1992. Nutrition management of dairy cows as a contribution to pollution control. Journal of Dairy Science. Vol. 1 (75) s. 345-357.

\section{THE FARMS AS A MAIN SOURCE OF AMMONIA IN THE ATMOSPHERE}

\section{S u m m a r y}

Objective of work was description influence of ammonia emission from farm yard manure storing plates on air quality at rural areas and assessment of factors which influence on size of emission. During 2003-2007 years were carried out over 100 daily measurements of ammonia emission from farm yard manure pits in selected milk farms by using micrometeorological method of passive dosimetry. Studies were conducted in typical working conditions. Research stated that annual emission of ammonia was between 318 and $698 \mathrm{~kg} \mathrm{~N}-\mathrm{NH}_{3}$. It expressed as nitrogen losses presents level between 35,2 to 44,0\% in dependence to initial amount of nitrogen deposited at manure pits. Mathematical model to assess ammonia emission was presented. This model contains the most important factors that influence on ammonia volatilization from farm yard manure pits in its continued working.

Keywords: farm, farm yard manure, storing, ammonia emission

Przestano do redakcji:30.05.2015r

Przyjęto do druku: 30.10 .2015 r.

DOI: $10.7862 / \mathrm{rb} .2015 .108$ 